\title{
Apocalyptic Landscapes in Old English Poetry and Homilies
}

\author{
Verena Klose
}

\section{Apocalypticism in Anglo-Saxon Literary Tradition}

Christianity and its eschatological focus had a significant impact on Anglo-Saxon literary culture. A major part of the surviving corpus deals with "last things," be it the biblical Last Days and the associated events of the end of the world, general fatalistic expressions of transience that concern one's own death, or the downfall of societies and cultures. Consequently, one could get the impression that apocalypticism was a particular obsession of Anglo-Saxon writers and teachers. However, in a Christian world-view the end of the world is only the end of the world as we know it. One can argue that the imminent end of the world constitutes both a demolition of the known order and the chance of renewal for the Christian soul, as it signifies the Last Judgement which marks the moment of truth for any believer. Depending on the outcome of said judgement, the apocalypse uncovers the access to a blissful afterlife in heaven or the sentence to eternal suffering in hell.

As the apocalypse is accompanied by various physical signs and events, it is interesting to look at the ways that the depiction of landscape creates and supports this ambiguous atmosphere of doom and hope. This paper's main focus is on the changes that take place in the natural world and the ways in which they relate to one's moral and mental state. The comparison between humanity's earthly dwelling and the transcendental landscapes of heaven and hell is especially relevant, 
though it remains to be determined whether the landscape in Old English poetry functions as a threat or a comfort to the human individual—or whether it can be both at different times. Furthermore, this paper will argue that the Anglo-Saxon vision of the Last Days can be seen in the broader context of an environmental theology that expresses the ambiguous relationship between humanity and its surroundings as it is shaped by Christianity and its perception of the natural world. In order to analyse the Christian relationship towards the doomed creation as the temporary home of humanity, I will examine poetry as well as religious prose.

Many of the surviving texts in Old English are preoccupied with eschatology and present imaginations of the last things, their onset, and process. The accounts of the events leading up to the Last Judgement and their impact on the natural world as they are described in the Old English poems at hand are heavily influenced by a literary apocalypticism that is based on the accounts found in the New Testament as well as in patristic commentaries and homilies. According to the Book of Revelation as well as the Gospels, the Last Days are marked by both physical and moral developments. While the appearance of false messiahs and the increased violence and aggression among nations are internal changes (Mark 13:22, Luke 21:25), ${ }^{1}$ the Bible also describes physical developments in great detail. This includes natural disasters such as earthquakes, thunder and lightning, and celestial events, such as stars falling from the sky and the darkening of sun and moon, as well as the emergence of beasts and animals attacking humans and their settlements (Apoc. 6, 8, and 9). The demolition of cultural settings such as cities, buildings, and kingdoms by wars, famines, and pestilence is also part of this endtime (Apoc. 6, 16, and 18). Both Ælfric and Wulfstan elaborate on these signs of doom in their homilies (Risden 39), which shows that they are part of a wellestablished tradition concerning the world's end.

\section{Sinful Degeneration: Human Existence in a Postlapsarian World}

Wulfstan, who became bishop of Worcester and archbishop of York in 1002, was one of the most influential authors who wrote about apocalyptic themes. Especially his early writings are evidence of his "theological preoccupation" (Gatch 105) with eschatological topics and his familiarity with the "entire range of ideas dealing with the destiny of mankind" (63). Five of Wulfstan's homilies deal with the Christian vision of the end of the world (Caie 11): De Antichristo, Secundum Matheum, Secundum Lucam, De Temporibus Antichristi, and Secundum Marcum. ${ }^{2}$ While he

\footnotetext{
${ }^{1}$ Biblical references are taken from the Douay-Rheims translation (The Holy Bible, Translated from the Latin V ulgate).

2 This paper uses Bethurum's edition of Wulfstan's homilies. Translations are my own, unless otherwise stated.
} 
comments in great detail on the Antichrist theme, he also elaborates on Doomsday and its specific circumstances. In Secundum Lucam (ed. in Bethurum 123-27), Wulfstan argues that "clæne wæs peos eorðe on hyre frumsceafte, ac we hi habbað syððan afylede swyðe and mid urum synnum pearle besmitene" (11. 27-29; "this earth was clean at its creation, but we have since polluted it greatly and defiled it severely with our sins"). With this statement, he expresses a notion that was prominent in environmental theology and which contributed to the complex and ambiguous relationship between Christianity and the natural world: while medieval scholars such as Augustine in his De civitate Dei argue that the creation in itself is originally and essentially beautiful, good, and useful to humanity (Neville 27-29), the harmonious perfection is destroyed by the Fall of Man. According to this, humankind's sins and crimes directly affect the world around them-as Wulfstan puts it, people pollute their god-given habitat by acting against the Creator's will.

This relationship between humanity's conduct and the moral state of the natural world is also reflected in Old English poetry: as a result of the moral deterioration, landscape is rarely described as exclusively pleasant and favourable. As Neville puts it, the natural world is rather seen as an "Other" that is depicted as alien and threatening to humanity (3). Furthermore, "nature" is oftentimes equated with "wilderness" which, in turn, is defined by "an opposition to the village, the dwelling, and the knowable zone" and experienced either as a "place of biblical exile" or as the habitat of dangerous wild animals (Mellor 104). This adds to the perception of the natural world as an entity that does not mean well and against which one has to defend oneself. In this concept, humans are not part of the environment, but rather its opponents or victims.

The rebellion of Adam and Eve in the Garden of Eden is seen as the root of this ambivalent relationship: it not only creates an emotional and spiritual alienation between them (and subsequently all of humanity) and God, but it also causes an estrangement from the natural world. Their misbehaviour results in their expulsion from Eden and the loss of all the privileges that were associated with the place. Adam and Eve have to lead a sorrowful existence full of hardships on earth as their exile, which Adam laments:

Hu sculon wit nu libban оððe on pys lande wesan,

gif her wind cymð, westan oððe eastan,

suðan oððe norðan? Gesweorc up færeð,

cymeð hægles scur hefone getenge,

færeð forst on gemang, se byð fyrnum ceald.

Hwilum of heofnum hate scineð,

blicð peos beorhte sunne, and wit her baru standað,

unwered wædo. Nys unc wuht beforan

to scursceade, ne sceattes wiht 
to mete gemearcod, ac unc is mihtig god,

waldend wraðmod. To hwon sculon wit weorðan nu? $(805-15)^{3}$

This passage shows the threats and discomforts that humans are confronted with in the postlapsarian world: the weather of their new dwelling is characterised as very harsh, with either extremely hot or extremely cold temperatures and other severe weather conditions like storms and hail. This is intensified by the lack of shelter and protection, adduced by Adam when he describes Eve and himself as helpless in the face of the cruel natural elements. Another trial is the arduous work that is now necessary in order to provide food and to make one's living. Therefore, the defilement of the sacred site of Paradise leads to its loss, so that the whole of creation falls together with humankind and functions now as the temporary home of exiles which is simultaneously a form of punishment for their misdeeds. However, one of Christianity's core teachings is the hope for salvation. Many theologians argue that in the Christian history of salvation, the natural world is orientated towards its eschatological conclusion in which the created order is finally restored (Northcott 199-203). The life of Jesus Christ and especially the events surrounding his crucifixion and resurrection serve to reaffirm and renew the "original goodness and moral significance" (200) of creation that have been lost after the Original Sin. Thus the case of humanity and the earth is not completely beyond hope, although it is certain that this reconciliation between humanity and creation can only take place after God's destruction of the current world order and the judgement of every soul. Until then, mankind must make do with the status quo.

The prelapsarian world and its physical features are ideal landscape models by which the natural world is measured. For instance, the description of the earthly paradise in The Phoenix ${ }^{4}$ is what one could consider an archetype of what AngloSaxons imagined to be a delightful and desirable landscape. It has a "beautiful" ("wlitig," 7a) and "delightful" ("wynsum," 13a) plain that is surrounded by "forests green" ("wealdas grene," 13b). Unlike the cold and harsh climate that Adam and Eve have to face after their expulsion, the place described in the poem is characterised by its moderate temperatures and the general absence of extreme conditions (14-19a and 57-64a). Even the landscape is free of topographical landmarks such as mountains, valleys, caves, or cliffs that would create a rough disturbance of the fair and flat plain (21-24a). Other attributes that are ascribed to the site include light ("sun-bearo," 33b), an overall greenness ("wealdas grene,"

\footnotetext{
3 "How shall we two now live or be in this land, if a wind comes here, from west or east, south or north? A cloud will rise up, a shower of hail will come pressing from the sky, will come mingled with frost, which will be sinfully cold. At times the bright sun will shine, blaze hot from the heavens, and we two will stand here naked, unprotected by clothes. There is nothing at all covering us two as a protection against the storm, nor any goods at all planned as our food, but rather mighty God, the ruler, is furious with the two of us. What must become of us two now?” (Anlezark 60-64).

${ }^{4}$ Text and translation from Jones 18-63.
} 
13b; "pa beamas a grene stondað," 35b-36a; "græs-wonge grene," 78), a flora with an abundance of fruits and flowers ("blostmum," 21a; "bledum," 71b), as well as a pleasant tranquillity ("smylte," 33a). Needless to say, humanity's current dwellingplace as it was described by Adam above falls far short of these expectations. This vision of an ideal landscape is rooted in the locus amoenus, the "pleasant place," which is a motif that can be found in the depiction of pastoral landscapes in Classical Western literature. Its main features are trees, grass, and water, which are often cultivated and arranged in a way that is both aesthetic and comforting to the human observer (Pearsall and Salter 9-12). In Old English literature, it is often adapted and merged with vernacular features and characterised by "adjectives of greenness, light or space and a noun denoting an open area of vegetation" (Kabir 144).

Interestingly, the poem Judgement Day $I I^{5}$ begins with a scene in which the speaker resides in an environment that is the epitome of the locus amoenus:

Hwæt! Ic ana sæt innan bearwe,

mid helme bepeht, holte tomiddes,

pær pa wæterburnan swegdon and urnon

on middan gehæge (eal swa ic secge);

Eac pær wynwyrta weoxon and bleowon

innon pam gemonge on ænlicum wonge

and pa wudubeamas wagedon and swegdon

purh winda gryre. $(1-8 a)^{6}$

From a literary perspective, the use of the locus amoenus motif is not surprising, because Judgement Day II is based on the Latin poem De die iudicii which has been ascribed to Bede or Aldhelm. Yet, it may appear as a peculiar opening to a poem about Doomsday. At first, the person speaking describes a setting in which the natural world is a pleasant and peaceful background; inside the sheltered grove, they are protected and are therefore able to enjoy the landscape with its plants, trees, and meadows, without feeling threatened by or exposed to it. It is only in the next lines that the mood suddenly changes as the poet makes use of pathetic fallacy: "Wolcn wæs gehrered, / and min earme mod eal wæs gedrefed" (8b-9; "The clouds were agitated and my poor mind was wholly troubled," Caie). The contrast between the outside world and the poet's inner state illustrates that the former tranquillity is deceptive, so that this antithesis represents and also criticises the human ignorance in the face of the imminent apocalypse. Firstly, this reveals that it is dangerous for the individual to imagine the soul to be safe and unaffected

\footnotetext{
${ }^{5}$ Quotations from Judgement Day II follow Caie's edition.

6 "Lo! I sat alone within a grove concealed with sheltering cover in the middle of a wood where the streams of water murmured and ran midst an enclosure (just as I say). Pleasant plants also grew and blossomed there midst the throng in this incomparable meadow, and the trees swayed and murmured through the force of the winds." (Caie).
} 
by worldly (mis-)deeds. The human being indulges in sins and vices while feeling safe and unbothered. Thus the speaker indicates that taking pleasure in the agreeable landscape without considering that it is transitory and will therefore not remain intact forever equates to the spiritual ignorance that many people display. They are blissfully unaware of the consequences that await them on the day of the great judgement and focus too much on temporary gratifications. Secondly, on a universal scale, the placidity of the place could be the proverbial calm before the storm, while the appearance of clouds foreshadows and announces the oncoming violent disturbances that will be brought on by the apocalypse.

\section{Eschatological Transformation: Natural Changes Heralding the Last Days}

One notion that is shared by many medieval Christian scholars is the idea that the world keeps degenerating and veering away from its original state. The analysis of apocalyptic Old English literature reveals that the world's degeneration and worsening are often mirrored in the landscape, which creates a reciprocal connection between the physical deterioration of the natural world and the moral decay of humanity. This can be seen in the natural disasters and monsters described in the poems Judgement Day I and II. The natural world is thus not only a marker of the end, it is also an instrument and means of God to exercise his power and dominance in order to punish his disobedient children.

When it comes to the apocalyptic events that change and destroy the natural world, one can see that the poem's vision draws heavily on the biblical account of the Last Days. The devastation that marks Christ's Second Coming affects all spaces of the natural world: the all-encompassing desolation alters land and oceans as well as the sky. The poet of Judgement Day II describes earthquakes and avalanches that cause the collapse of mountains (99-101), the sea as it is churned by storms (102-03), the darkening of sun and moon (104-06; 108-10), as well as the falling of stars (107):

Eall eorðe bifað, eac swa pa duna

dreosað and hreosað, and beorga hliðu bugað and myltað, and se egeslica sweg ungerydre sæ eall manna mod miclum gedrefeð.

Eal bið eac upheofon sweart and gesworcen, swiðe gepuxsað, deorc and dimhiw, and dwolma sweart. ponne stedelease steorran hreosað, and seo sunne forswyrcð sona on morgen, 
ne se mona næfð nanre mihte wiht,

pæt he pære nihte genipu mæge flecgan. $(99-110)^{7}$

These phenomena are an omen of the things to come; they herald the procedures of Judgement Day, i.e. the gathering of "eal Adames cnosl eorðbuendra" ("all earth-dwellers of Adam's race," 130) in front of God who sits on his heavenly throne and summons them to decide on their respective fates. By referring to humanity as "Adam's race", the poet connects the imminent end of the world to its very beginning; the history of mankind began with Adam and now finds its closure with the Lord's judgement of all souls that live and have lived since then. As a result, people are petrified and their minds are greatly troubled ("eall manna mod miclum gedrefeð," 103), both by the calamities happening around them and the prospect of being judged unfavourably. In this context, the use of the verb gedrefan in order to describe the men's mindset seems to be an understatement, but it also connects this part of the poem with its beginning. Thus it illustrates that there is a strong link between the sentient individual and their surroundings, because the physical conditions influence the mental state as well as the perception and assessment of oneself in both instances. Therefore, the passage quoted above also emphasises that the environmental changes themselves are already part of the impending punishment: it appears as if the natural world is unleashed and out of control as it strikes against humanity.

The same sentiment is expressed by Wulfstan in the homily Secundum Lucam, in which the aforementioned connection between the worsening state of the world due to humanity's sins and the occurrence of natural disasters is one of the main themes:

And forðy us eac swencað and ongean winnað manege gesceafta, ealswa hit awriten is: Pugnabit pro Deo orbis terrarum contra insensatos homines. Đæt is on Englisc, eal woruld winneð swyðe for synnum ongean pa oferhogan pe Gode nellað hyran. Seo heofone us winð wið ponne heo us sendeð styrnlice stormas and orf and æceras swyðe amyrreð. Seo eorðe us winð wið ponne heo forwyrneð eorðlices wæstmas and us unweoda to fela asendeð. Eac hit awriten is, ðæt sunne apystrað ær worulde ende and mona adeorcað and steorran hreosað for manna synnum. (11. $34-43)^{8}$

\footnotetext{
7 "All the earth will shake, and the hills too will fall and perish, and mountain slopes will fall down and dissolve, and the terrifying noise of the ranging sea will greatly trouble all men's minds. All the heavens will also become black and darkened, extremely overcast, dark and murky with the blackness of chaos. Then the stars, displaced, will fall and the sun will become immediately dark in the morning; nor will the moon have any might at all to banish the darkness of the night" (Caie).

8 "And because of that many created things also torment us and fight against us, just as it is written: The whole world will fight for God against foolish people. That is in English, all of the world will fight greatly on account of sin against the proud ones who are unwilling to listen to God. The heaven strives against us when it sends us harsh storms that severely damage cattle and fields. The earth strives against us when it denies earthly fruits and sends us too many ill weeds. It is also written that
} 
According to Lionarons, Wulfstan cites Wisdom 5:219 here and then adds some examples of his own in order to support his claim (53). As Wulfstan bases this homily on Luke 21, his examples correspond to the biblical accounts and include storms and plagues that destroy the harvest and kill the cattle, darkening of sun and moon, falling of the stars, and the appearance of the Antichrist (11. 38-48). Similar to the circumstances in Judgement Day II, the disintegration of God's creation is the first and most important sign of the end. Both texts mention the land, the sea, and the celestial bodies as natural objects that were created and arranged by God in the beginning of Genesis; Neville calls them the "trio of sea, earth, and heaven" (142) that uniformly appears in texts mentioning the creation. The fact that the created order of the "trio" begins to fall apart at the end is evidence of the Christian world view: by referencing to significant details of Creation, the poet revisits this very first act of God. By looking at the beginning, it becomes clear to the reader that in its downfall, the world reaches its eschatological conclusion. In this paragraph of Secundum Lucam, creation has lost its initial purity and consequently turns into a weapon against humans and their immoral behaviour. Former certainties are no longer fixed; for instance, people can no longer rely on being able to feed themselves by cultivating the soil, although that has been the case ever since the loss of Eden. This adds to their helplessness and forces them to realise that they are completely at God's mercy. Especially from an ecocritical perspective it is most striking that Wulfstan's interpretation of the natural world is rather ambiguous in this context. It is not clear whether he understands the environment as an instrument controlled by God or whether nature has an agency of its own. This struggle of authority and autonomy is also discussed by Neville: she points out the "contradiction between the natural world representing threats to humanity and the natural world representing the Saviour's power" (163) that leads to the "unresolved paradox" (177) that is God's relationship to nature. Especially the idea of a hostile environment causes a problem for the Christian conception of the world: God as a destructive and powerful ruler who uses his creation in order to strike against his children is not compatible with the image of a forgiving and loving God as it is evoked in the New Testament. However, the thought that nature could in fact be beyond any divine control and thus able to exercise power on its own is equally unacceptable. While Old English poetry does not address this issue directly, Neville observes that it often portrays nature as a "semi-autonomous agent" (171) that serves as a means of demonstrating God's power, by reflecting either his divine design or his ability to overcome and control the adverse natural forces (177). In the case of apocalypticism, however, one can argue that the natural disasters function both as a punishment for humankind having

the sun will become dark before the end of the world and the moon will darken and the stars will fall because of men's sins."

9 "And he [the Lord/Jesus Christ] will sharpen his severe wrath for a spear, and the whole world shall fight with him against the unwise" (Wisd. 5:21). 
lived in sin and as a marker for the fundamental cosmological changes that the final judgement will bring.

\section{Purifying Destruction: The Cleansing of Soul and Landscape by Fire and Water}

One theme that has been adapted prominently in many apocalyptic religious writings is destruction by fire: the Bible describes how a censer filled with fire is cast on the earth where it burns great parts of the land, mountains, and sea (Apoc. 5:8). Having said that, fire is not the only means of destruction and subsequent purification in the analysed material. For instance, Wulfstan compares the Doomsday fires to Noah's flood: “And witodlice ealswa flod com hwilum ær for synnum, swa cymð eac for synnum fyr ofer mancynn and ðærto hit nealæcð nu swyðe georne" (11. 7-9). ${ }^{10}$ Thus in an allegorical reading one can say that the Flood prefigures the consumption by fire at the world's end. In the case of Wulfstan's homily, Gatch argues that he may have been inspired by Ælfric, who also links both the Flood and the burning of Sodom to Judgement Day in De die indicii (109). However, Lionarons argues that due to the dating of Ælfric's homily, it is more likely that Wulfstan used the same source as a basis for his arguments. While the Book of Revelation only mentions blazing fires as an instrument of cleansing, Lionarons identifies Luke 17:26 and 17:29-30 as the origin of a Doomsday vision that includes both fire and water and that compares the circumstances of the apocalypse with the first biblical natural disaster (52). ${ }^{11}$ The same connection is also made in The Phoenix when the poet declares that the earthly paradise remained unaffected by the "wætres prym ... mere-flod" ("the water's force ... the flood of water," $41 \mathrm{~b}$; 42b) because God protected it from the ydfaru ("waves," 44b) and hreore wagas ("fierce waters," 45b). Because of that, the place will stay unviolated and intact until the Day of Judgement when the bal ("fire" or "flame," 47b) will come. By singling out the earthly paradise as an exceptionally pure site, the poet associates the violation of landscape by natural forces such as water and fire directly with the divine sanction of moral failures.

The poem Judgement Day $I^{12}$ even depicts fire and water in a specific sequence. It begins with an allusion to a flood that is brought upon the earth by God: "Đæt gelimpan sceal pætte lagu flowed, / flod ofer foldan" ("It must come to pass that water will flow, a flood over the earth," 1-2a). After the flooding, which brings

\footnotetext{
10 "And certainly just like the flood came once before because of sin, so a fire will come over mankind as well because of sin and we are rapidly approaching that time now."

11 "And as it came to pass in the days of Noe, so shall it be also in the days of the Son of man" (Luke 17:26); "and in the day that Lot went out of Sodom, it rained fire and brimstone from heaven, and destroyed them all. Even thus shall it be in the day when the Son of man shall be revealed" (Luke 17:29-30).

${ }^{12}$ Text and translation are taken from Jones 232-41.
} 
the death of every living creature (2b-3a), God will induce a large and fiercely burning fire to thoroughly destroy the earth $(6 b-7 a)$ :

Hat bið onæled,

sippan fyr nimeð fildan sceatas,

byrnende lig beorhte gesceafte;

bið eal pes ginna grund gleda gefylled,

repra bronda $(9 \mathrm{~b}-13 \mathrm{a})^{13}$

Along with the resident demons and devils, the disobedient sinners have to endure the eternal flames as a punishment (18), while the people who have led pure and pious lives are granted eternity in heaven (60-67a). Throughout Judgement Day $I$, the poet also mentions other apocalyptic signs such as the absence of light due to the darkening of the stars (45), and earthquakes (112b-13), but his main focus is the fiery calamity as he repeatedly describes the Doomsday and hell fires in great and terrifying detail (50b-59; 116-19). In this way, he ensures that his audience realises and envisions the torments that will await them if they do not lead a lifestyle that is agreeable to God. Risden interprets this fire as a "sacramental purification" and calls it the "final baptism" (37) that complements the first baptism carried out by the Flood. Subsequently, the flames turn into the allencompassing eternal fire of hell's pit in which the damned soul will have to reside from now on. Once the fires will have cooled, there will be nothing but dire emptiness in the world. In analogy with the useless and chaotic void that the cosmos was before God's intervention, after the fire there will be nothing left except the watres sweg ("the sound of the water," 38). In Judgement Day II, the land after the great firestorm is also referred to as emtig ("vacant" or "empty," 149a), which corresponds to the idleness of the world before God's exercise of divine strength. Thus one can read the purification by fire that eradicates all life on earth as an attempt of reversing the process in which the creation had been spoilt.

The poet of Judgement Day II assigns similar cleansing qualities to fire and water. On the one hand, they admonish themselves as a sinful person who should show their remorse by crying (26-42). In the physical demonstration of one's regret, the tears function as a means of purging the body of the immoral acts that it has committed. Thus the flowing teardrops mirror the purification of the earth by the flooding and therefore symbolise a moral cleansing by water that affects nature and body likewise. Additionally, later on in the poem the author also alludes to the Flood by referring to the ignited fires as a rede flod, a "cruel flood" (166a) that incinerates the unfortunate souls. On top of that, he or she compares the wrongful and corrupt state of their soul to lying in dirt:

13 "Heat will be stoked, then fire will claim the surfaces of the earth, searing flame grip the bright creation. With glowing coals, furious burning, this whole, vast region will be filled." 
Hwæt ligst pu on horwe leahtrum afylled, flæsc, mid synnum? Hwi ne feormast pu mid teara gyte torne synne? $(77-79)^{14}$

This passage is another reference to the polluted earth (horu) and the general connection between materiality, be it body or nature, and the commitment of sins. Later on in the poem, the author describes how every person will be consumed by the fire until they are completely cleansed from the filth (155-58). The notion of a fiery purification that "disinfects" the contamination caused by corrupt behaviour is not exclusive to this text, it can be found in other poems as well. For instance, the poet in Christ III ${ }^{15}$ also denounces the sinful behaviour of his fellow men that ruins the creation which then needs to be cleansed from the weoruldwidl (1006a), the "pollution of worldly filth." After this, Christ laments that people have foully defiled both "pæt selescot pæt ic me swæs on pe / gehalgode, hus to wynne" (1480-81; "that dwelling that I myself sanctified for you, as a house for delight") and "pone lichoman pe ic alysde me feondum of fæome" (1484-85b; "the body that I delivered from the enemy's embrace"). This example illustrates the connection between the world (as humanity's assigned abode) and the body (as the soul's house) in terms of their inclination toward impure and immoral acts. The "pollution" by committing sins therefore affects the inner landscape of the soul as well as the outer landscapes of creation.

The flames that will spread over the whole surface of the earth are described in Judgement Day II as more violent and powerful than any normal fire as they truly assume apocalyptic dimensions: the fire will be poisonous (attren, 146b) and no living creature will be able to withstand it (147b-48). The fire is almost envisioned as a sentient being. The poet personifies and anthropomorphises it by describing it as reðе ("cruel," 153a) and as a wrecend (155a), an avenger that neither holds back from its violent behaviour nor takes pity on the damned souls (152-58). Moreover, he or she associates fire with the appearance of monsters ("foul serpents," 168b; "cruel serpents," 212, with "fiery teeth," 213b) and the "horrible torments of hell" (190b). Hence, one can argue that the outbreak of the apocalyptic fires transforms the earth into a hell-like place or even a preliminary stage of hell, as the destruction of the environment and the burning of souls foreshadows the torture that the soul has to endure in hell. However, hell is depicted as a place in which fire and extreme cold are combined in order to intensify the punishments (191-93). Once again, this represents the human fear of being exposed and powerless in the face of natural forces. The imagery of either being severely burned or gnashing one's teeth due to the unbearable frost is a striking contrast to the locus amoenus mentioned at the beginning of the text and the portrayal of Paradise with

\footnotetext{
14 "Why, flesh, do you lie in filth, filled with vices and sins? Why do you not cleanse distressing sins by shedding tears?"

${ }^{15}$ References to Christ III follow Krapp and Dobbie throughout; translations are my own.
} 
which the poet concludes the poem. In accordance with the inexpressibility topos, they choose to represent heaven by describing what it is not, namely a place of physical and psychological deprivation. For the happy souls who are allowed to reside there, the entry into Paradise equates to the return to the original state as it used to be in the Garden of Eden. The saved souls are eternally protected from death, hardships, pain, and sorrow, while they inhabit a landscape that does not have any harsh weather and which is therefore perceived as pleasant and agreeable (255-72).

However, one has to remember that the Christian apocalyptic outlook is not the renewal or restoration of the old world, but rather the foundation of a new one, which means that this utopian vision of a reconstructed Edenic site is only possible after the complete destruction of the (con-)temporary world. For instance, the Apocalypse of Saint John tells of the kingdom of God in which the heavenly city Jerusalem is constructed after the old and flawed world has been destroyed (Apoc. 21). The fact that it is a cityscape that stands at the end of the apocalyptic process can be read as a triumph over the hostile and uncultivated wilderness. Furthermore, the dualism of beautiful (moderate, tranquil, cultivated) and horrible (extreme, disturbing, wild) landscapes represents the cosmic battle between good and evil powers; it also illustrates what Haught calls the eschatological approach to environmental theology, because these "good" landscapes can only be found in past and future ages. He argues that in answer to nature's perceived status of transience and incompletion, Christianity proposes that the believer accept its imperfection as a promise for future fulfilment and focus on the security of their immortal soul instead (277-83).

\section{Conclusion: The Apocalypse as the Ultimate Unleashing of Divine Power and Natural Forces}

In conclusion, this paper has shown that the portrayal of the natural world in the apocalyptic writings of Anglo-Saxon England is characterised by the tension between the earth as humanity's imperfect and transitory dwelling-place and the outlook of paradise as the eternal home. There were pleasant landscapes before the current state of things (the Garden of Eden) and there will be after (the heavenly paradise), but in the here and now, the world is in a state of pollution. Both poets and preachers remind the audience of the cause of this corruption and defilement: the Fall of Man. The subsequent misdeeds of humanity continue to desecrate God's creation even more, so that the Lord has no other choice but to initiate the apocalypse as an overall purification scheme. In this context, it seems only fitting that the polluted world is also the setting of the great and final judgement. In this instance, nature appears as the threatening Other from which God protects only the people who are in his favour. As this paper has pointed out, the 
exact role of nature in the apocalypse is ambiguous and open to interpretation: the analysed texts allow the understanding of nature as an instrument of God as well as a reading of nature as a (semi-)autonomous agent that takes revenge on the people who have defiled it. In any case, the apocalyptic landscapes are a cause of great pain and distress for humanity: as the state of things progressively becomes more chaotic, people have to face frightening natural phenomena such as earthquakes and meteor showers and the loss of former certainties such as being able to feed themselves or living peacefully on their native land. The relation between this state and the moral deterioration has been emphasised in the poems as well as by Wulfstan in his homily Secundum Lucam. In the eyes of Christianity, the current world is often perceived as little more than a temporary home and exile because it cannot bear comparison with the ideal landscapes of Eden and heaven.

Furthermore, when it comes to the actual destruction of all the earthly spaces, this paper has highlighted the particularly interesting connection between the Flood of Noah and the Doomsday fires. Both are means to make a clean sweep and to obliterate the sin-ridden earth including all of its inhabitants. However, according to the Anglo-Saxon texts at hand these two events are occasionally combined and thus parts of the apocalypse that both mark the imminent end and collapse of the world order. As there are many more texts that explicitly and implicitly deal with the last things, this paper could only deal with extracts from a small selection; there are definitely several other texts, especially homilies by Æelfric and Wulfstan, that are worth further examination in order to determine the currency of this motif in Anglo-Saxon literature.

All in all, one can observe that the poems studied portray the apocalyptic natural world as an intensified version of its already threatening self. The events of Doomsday cause the worsening of the world that consequently approximates hell in its characteristics and impact on the human individual. Wulfstan also blames humanity for abusing the creation by sinning against God and predicts the signs of doom that will be the result of said sinful behaviour. In all these accounts, the natural world is perceived as an entity that is immensely powerful and potentially destructive and surrounded by a morally ambiguous atmosphere. In times of global warming and an increasing number of natural disasters, the Anglo-Saxon descriptions of this unleashed potential, be it by God's order or as nature's independent act of revenge against humanity, are strikingly similar to contemporary ecological dystopias, which illustrates the universality of the expressed fear of being subject to nature's devastating forces. 


\section{Works Cited}

Bethurum, Dorothy, ed. The Homilies of Wulfstan. Oxford: Clarendon Press, 1957.

Caie, Graham D., ed. and trans. The Old English Poem Judgement Day II. Cambridge: D. S. Brewer, 2000.

Gatch, Milton McCormick. Preaching and Theology in Anglo-Saxon England. Toronto: U of Toronto P, 1977.

Haught, John F. "Christianity and Ecology." This Sacred Earth: Religion, Nature, Environment. Ed. Roger S. Gottlieb. New York and London: Routledge, 1996. 270-96.

The Holy Bible, Translated from the Latin Vulgate. New York: Dunigan, 1854.

Jones, Christopher A., ed. and trans. Religious and Didactic. Dumbarton Oaks Medieval Library 15. Vol. 1 of Old English Shorter Poems. 2 vols. Cambridge, MA: Harvard UP, 2012.

Kabir, Ananya Jahanara. Paradise, Death and Doomsday in Anglo-Saxon Literature. Cambridge: Cambridge UP, 2001.

Krapp, George Philip, and Elliott van Kirk Dobbie, eds. The Exeter Book. 3rd ed. London: Routledge, 1966.

Lionarons, Joyce Tally. The Homiletic Writings of Archbishop Wulfstan. Woodbridge, Suffolk D. S. Brewer, 2010.

Mellor, Leo. "The Lure of Wilderness." The Cambridge Companion to Literature and the Environment. Ed. Louise Westling. Cambridge: Cambridge UP, 2014. 104-18.

Neville, Jennifer. Representations of the Natural World in Old English Poetry. Cambridge: Cambridge UP, 1999.

Northcott, Michael S. The Environment and Christian Ethics. Cambridge: Cambridge UP, 1996.

Pearsall, Derek, and Elizabeth Salter. Landscapes and Seasons of the Medieval World. London: Elek, 1973. 